\title{
Improvement of in vitro-produced bovine embryo treated with coagulansin-A under heat-stressed condition
}

\author{
Imran Khan ${ }^{1, *}$, Kyeong-Lim Lee ${ }^{1, *}$, Lianguang Xu ${ }^{1}$,Ayman Mesalam ${ }^{1}$, M M R Chowdhury ${ }^{1}$, \\ Myeong-Don Joo', Ihsan-ul-Haq 3 , Bushra Mirza ${ }^{4}$ and Il-Keun Kong ${ }^{1,2}$ \\ ${ }^{1}$ Department of Animal Science, Division of Applied Life Science (BK21 Plus), ${ }^{2}$ Institute of Agriculture and Life \\ Science, Gyeongsang National University, Jinju, Gyeongnam Province, Republic of Korea, ${ }^{3}$ Department of \\ Pharmacy, Faculty of Biological Sciences, and ${ }^{4}$ Department of Biochemistry, Quaid-i-Azam University, \\ Islamabad, Pakistan \\ Correspondence should be addressed to I-K Kong; Email: ikong7900@gmail.com
}

*(I Khan and K Lee contributed equally to this work)

\begin{abstract}
Heat stress has large effects on reproduction including conception rate in cattle. In this study, we examined the effects of coagulansin-A (coa-A), a steroidal lactone, on acquired thermo tolerance during in vitro production of bovine embryos. Oocytes were incubated in in vitro maturation (IVM) media with or without coa-A at two different temperatures, $40.5^{\circ} \mathrm{C}$ and $42^{\circ} \mathrm{C}$, for $20 \mathrm{~h}$. The treatment of coa-A significantly improved blastocyst development only at $40.5^{\circ} \mathrm{C}(P<0.05)$. Interestingly, immunofluorescence analysis demonstrated that coa-A induced heat shock protein 70 (HSP70) and phosphatidylinositol-3-kinase (PI3K), but significantly attenuated nuclear factor kappa B (NF- $\mathrm{B}$ ) and cyclooxygenase-2 (COX2). To determine the expression patterns of related genes at the transcription level, qRT-PCR was performed. Expression of $H S P 70$ and $P I 3 K$ was elevated, whereas expression of $N F$ - $K B$, COX2 and inducible nitric oxide synthase (iNOS) was significantly $(P<0.05)$ downregulated in the coa-A-treated group compared with the control group. Moreover, pro-apoptotic genes were downregulated, and antiapoptic genes were upregulated in the coa-A group. We also counted the total cell number and apoptotic nuclei at the blastocyst and found that more cell numbers (143.1 \pm 1.5$)$ and less apoptotic damages $(6.4 \pm 0.5)$ in the coa-A treatment group comparing to control group $(131.4 \pm 2.0$ and $10.8 \pm 0.5)$, indicating the enhanced embryo quality. In conclusion, our results demonstrate that the coa-A not only improved the blastocyst development in vitro but also increased their resistance to heat stress condition through induction of $H S P 70 / P I 3 K$.

Reproduction (2017) 153 421-431
\end{abstract}

\section{Introduction}

Bovine oocytes are used to generate in vitro-produced embryos throughout the world. Embryos are derived from immature oocytes and oocytes are obtained from slaughtered cattle, because they are easily available and inexpensive (Jeong et al. 2009). However, the efficiency of in vitro production (IVP) is poor, because the quality of the embryos produced is lower than that of in vivo (Lonergan et al. 2006). Exposure of embryos to oxidative stress (OS) has deleterious effects on their development during IVP (Guerin et al. 2001). The balance between OS and antioxidants is maintained in vivo, whereas the level of reactive oxygen species (ROS) exceeds the cellular antioxidant concentration and causes OS in vitro (Combelles et al. 2009). Withanolides obtained from Withania somnifera are widely used in India and Pakistan (Ihsan-Ul-Haq et al. 2013). Withanolides are steroidal lactones that have various pharmacological uses, have positive roles in hemoglobin improvement and weight gain and are antioxidants that scavenge ROS (Ziauddin et al. 1996). Withanolides also have a dynamic anticancer role, operating as anticancer agents in cancer cell lines by enhancing apoptosis, and are also used to treat Alzheimer's disease, Parkinson's disease and dementia (Wang et al. 2012). Coagulansin-A (coa-A) is a withanolide derivative, and we reported for the first time that it improves bovine embryo development in vitro in normal culture conditions (Khan et al. 2016). Various environmental factors affect the fertility of dairy animals. Of these, heat stress or heat shock is the most important, because it reduces the developmental competence of oocytes (Yadav et al. 2013). During the early stage of folliculogensis, heat stress damages the ovarian pool of oocytes (Roth et al. 2001). Heat stress also greatly affects 
the conception rate, and the conception rate is reduced to $20-30 \%$ during hot seasons (Cavestany et al. 1985, De Rensis et al. 2002). Heat stress reduces cytoplasmic and nuclear maturation, the functions of surrounding cumulus cells, and mitochondrial activity and induces apoptosis (Roth 2008, Hansen 2009, Nabenishi et al. 2012). Great economic losses are associated with livestock during hot seasons, because the temperature fluctuation causes heat stress that affects the fertility of cattle and other animals (Stott 1961). Special attention is needed to counterbalance the drastic effects of global warming and environmental changes on livestock by reducing losses due to heat stress.

The aim of this study was to examine the positive effect of coa-A on the development of bovine embryos in heat stress conditions in vitro.

\section{Materials and methods}

\section{Regents and approval of experiments}

All chemicals and reagents were obtained from SigmaAldrich. The care and use of laboratory animals as well as the experiments were performed following Gyeongsang National University guidelines and rules (approval no. GAR110502-X0017).

\section{Isolation and characterization of coagulansin-A}

This method has been elaborated in detail in the Supplementary extended section. Briefly, the plant material was collected, sorted out for any foreign material, diseased or deteriorated parts. Then, it was shade dried with continuous agitation every 6 hourly and then crushed in a grinding mill. A total of 10-kg shade dried and crushed aerial parts without fruits (leaves and stems only) were taken and macerated in
$30 \mathrm{~L}$ of solvent by occasional shaking for 3 days. Mixture of chloroform and methanol (1:1) was used as extraction solvent. Filtrate of extraction was dried by vacuum distillation. It was then subjected to solvent extraction and normal phase preparative chromatography to isolate $50 \mathrm{mg}$ of coagulansin-A. The compound was characterized by performing 2D NMR and LC-MS experiments, and purity was $98.6 \%$ (Ihsan-Ul-Haq et al. 2013).

\section{Experimental design}

The goal of this study was to determine the protective effect of coa-A against heat stress in IVM media for blastocyst development. For this purpose, the optimal concentration of coa-A $(5 \mu \mathrm{M})$ was selected based on our previous data (Khan et al. 2016). Oocytes treated with $5 \mu \mathrm{M}$ coa-A were compared with the untreated control group. Both the coa-Atreated and control groups were exposed to heat stress at $42^{\circ} \mathrm{C}$ for 2, 5, 10 and $20 \mathrm{~h}$. However, at this temperature, there was no significant difference in blastocyst development between the control and coa-A-treated group. Then, we exposed both groups to a heat stress at $40.5^{\circ} \mathrm{C}$ for $2,5,10,20$ and $24 \mathrm{~h}$ and then cultured at a normal temperature $\left(38.5^{\circ} \mathrm{C}\right)$. At $40.5^{\circ} \mathrm{C}$, we found the significant developmental competence to blastocyst between the control and coa-A-treated group after $2 \mathrm{~h}(26.6$ and 36.1), $5 \mathrm{~h}$ (24.7 and 32.6), $10 \mathrm{~h} \mathrm{(21.8} \mathrm{and} \mathrm{29.2)} \mathrm{and} 20 \mathrm{~h}$ (18.6 and 24.6) except $24 \mathrm{~h}$ (14.2 and 15.2). We focused on blastocyst development at $40.5^{\circ} \mathrm{C}$ after 20 -h heat stress, because it was the maximum time up to which the coa- $\mathrm{A}$ shows its activity for blastocyst development. The study was completed in six replications.

\section{Recovery of cumulus-oocyte complexes (COCs)}

Ovaries of Korean native cows (Hanwoo) were obtained from a local abattoir, placed in physiological saline $(0.9 \% \mathrm{NaCl})$ at approximately $35^{\circ} \mathrm{C}$ and transported to the laboratory within

Table 1 Primer list for RT-PCR.

\begin{tabular}{|c|c|c|c|}
\hline Gene & Primer sequence & Accession no. & Product size (bp) \\
\hline HSP70.1 & $\begin{array}{l}\text { F: GAGTCGTACGCCTTCAACAT } \\
\text { R: ACTTGTCCAGCACCTTCTTC }\end{array}$ & U09861 & 94 \\
\hline PI3K & $\begin{array}{l}\text { F: TCAACCATGACTGTGTGCCA } \\
\text { R: CCATCAGCATCAAATTGGGCA }\end{array}$ & NM_174574.1 & 234 \\
\hline$N F-\kappa B$ & $\begin{array}{l}\text { F: TGGCGGAATTACCTTCCATAC } \\
\text { R: CATCACTCTTGCCACAACTTTC }\end{array}$ & DQ464067 & 110 \\
\hline COX2 & $\begin{array}{l}\text { F: CTGACCCATACAAGCACGATAG } \\
\text { R: TCGTAAAGAAGGAAGAGCAATTAGA }\end{array}$ & DQ347627.1 & 99 \\
\hline iNOS & $\begin{array}{l}\text { F: CGAGCTTCTACCTCAAGCTATC } \\
\text { R: CTGGCCAGATGTTCCTCTATTT }\end{array}$ & DQ676956.1 & 84 \\
\hline P53 & $\begin{array}{l}\text { F: CTATGAGATGTTCCGAGAGC } \\
\text { R: CTCTCTCTTGAGCATTGGTT }\end{array}$ & NM_174201.2 & 153 \\
\hline$P 21$ & $\begin{array}{l}\text { F: GCAAATATGGGTCTGGGAGA } \\
\text { R: AAATAGTCCAGGCCAGGATG }\end{array}$ & NM_001098958.2 & 112 \\
\hline$B A X$ & $\begin{array}{l}\text { F: CACCAAGAAGCTGAGCGAGTGT } \\
\text { R: TCGGAAAAAGACCTCTCGGGGA }\end{array}$ & NM_173894 & 118 \\
\hline Caspase 3 & $\begin{array}{l}\text { F: CCCAAGTGTGACCACTGAAC } \\
\text { R: CCATTAGGCCACACTCACTG }\end{array}$ & NM_001077840 & 169 \\
\hline$B C L-2$ & $\begin{array}{l}\text { F: TGGATGACCGAGTACCTGAA } \\
\text { R: GAGACAGCCAGGAGAAATCAAA }\end{array}$ & NM_001166486.1 & 123 \\
\hline GAPDH & $\begin{array}{l}\text { F: CCCAGAATATCATCССТGCT } \\
\text { R: CTGCTTCACСАССТTCTTGA }\end{array}$ & NM_001034034 & 185 \\
\hline
\end{tabular}


Table 2 Cleavage and developmental rates of bovine embryos generated from oocytes treated with $5 \mu \mathrm{M}$ coagulansin- $\mathrm{A}$ at heat stress condition of $40.5^{\circ} \mathrm{C}$ after various time intervals.

\begin{tabular}{|c|c|c|c|c|c|}
\hline \multirow{2}{*}{$\begin{array}{l}\text { Exposed time for } \\
\text { heat shock }(\mathrm{h})\end{array}$} & \multirow[b]{2}{*}{ Treatments } & \multirow[b]{2}{*}{ No. of oocytes } & \multirow{2}{*}{$\begin{array}{c}\text { No. of } \\
\text { presumed zygote }\end{array}$} & \multicolumn{2}{|c|}{ No. $(\%)$ of embryos developed to } \\
\hline & & & & Cleavage & Blastocyst \\
\hline \multirow[t]{2}{*}{2} & Control & 195 & 172 & $138(80.2)^{\mathrm{a}}$ & $46(26.6)^{\mathrm{a}}$ \\
\hline & Coa-A & 195 & 170 & $140(82.3)^{\mathrm{a}}$ & $60(36.1)^{b}$ \\
\hline \multirow[t]{2}{*}{5} & Control & 195 & 168 & $131(78.5)^{\mathrm{a}}$ & $41(24.7)^{\mathrm{a}}$ \\
\hline & Coa-A & 195 & 165 & $130(79.3)^{\mathrm{a}}$ & $53(32.6)^{b}$ \\
\hline \multirow[t]{2}{*}{10} & Control & 195 & 167 & $129(77.3)^{\mathrm{a}}$ & $35(21.8)^{\mathrm{a}}$ \\
\hline & Coa-A & 195 & 165 & $129(78.1)^{\mathrm{a}}$ & $47(29.2)^{b}$ \\
\hline \multirow[t]{2}{*}{20} & Control & 265 & 227 & $172(75.7)^{\mathrm{a}}$ & $42(18.6)^{\mathrm{a}}$ \\
\hline & Coa-A & 265 & 231 & $176(76.2)^{\mathrm{a}}$ & $57(24.6)^{b}$ \\
\hline \multirow[t]{2}{*}{24} & Control & 195 & 161 & $84(52.1)^{\mathrm{a}}$ & $23(14.2)^{\mathrm{a}}$ \\
\hline & Coa-A & 195 & 164 & $88(53.7)^{\mathrm{a}}$ & $25(15.2)^{\mathrm{a}}$ \\
\hline
\end{tabular}

This study was completed in six replications.

a,b Values with different superscripts are significantly different $(P<0.05)$.

$2 \mathrm{~h}$ after slaughter. Ovaries were washed with Dulbecco's phosphate-buffered saline (D-PBS), and COCs were recovered as described by Deb and coworkers (Deb et al. 2011). In brief, an 18-gauge needle attached to a vacuum pump was used to aspirate COCs from follicles with a diameter of $2-8 \mathrm{~mm}$. The fluid obtained from follicles was expelled into $\phi$ $100 \mathrm{~mm}$ petri dishes containing TL-HEPES medium $(114 \mathrm{mM}$
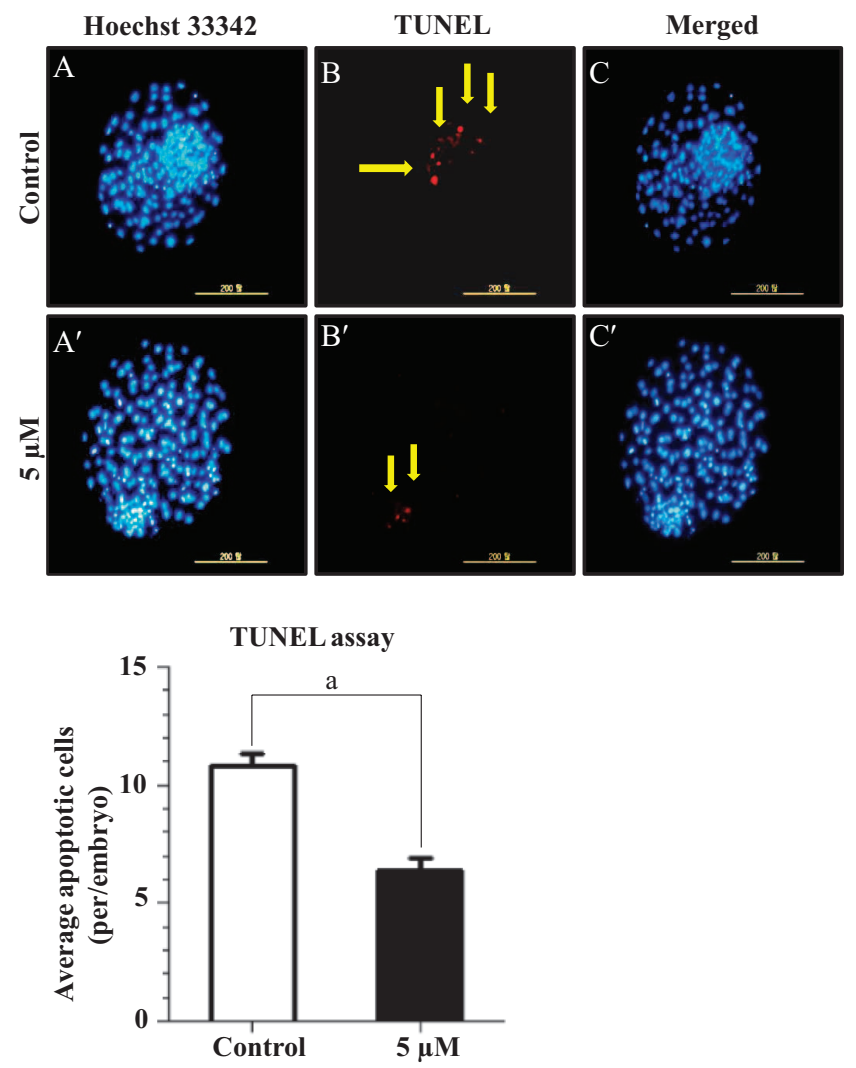

Figure 1 Representative images of bovine embryos stained with Hoechst 33342. Apoptotic cells were identified by TUNEL. The corresponding images were merged. (A, B, C) Control group. ( $A^{\prime}, B^{\prime}$, $\left.C^{\prime}\right)$ Group treated with $5 \mu \mathrm{M}$ coagulansin-A. Scale bar, $200 \mu \mathrm{m}$. Apoptotic cells are indicated by yellow arrows. The graph shows the number of apoptotic cells per embryo. The symbol a shows the significant difference $(P<0.05)$ between the control and treated group. sodium chloride, $3.2 \mathrm{mM}$ potassium chloride, $2 \mathrm{mM}$ sodium bicarbonate, $0.34 \mathrm{mM}$ sodium biphosphate, $10 \mathrm{mM}$ sodium lactate, $0.5 \mathrm{mM}$ magnesium chloride, $2 \mathrm{mM}$ calcium chloride, $10 \mathrm{mM}$ HEPES, $1 \mu \mathrm{L} / \mathrm{mL}$ phenol red, $100 \mathrm{IU} / \mathrm{mL}$ penicillin and $0.1 \mathrm{mg} / \mathrm{mL}$ streptomycin) and imaged with a stereomicroscope. Good-quality oocytes with more than three layers of compact cumulus cells and homogenous cytoplasm were selected for maturation and then washed three times in TL-HEPES medium.

\section{In vitro maturation (IVM) of oocytes}

After selection, COCs were cultured in IVM medium as described by Deb and coworkers (Deb et al. 2011). In brief, the COCs were washed three times in IVM medium (TCM-199) supplemented with $10 \%(\mathrm{v} / \mathrm{v})$ fetal bovine serum (FBS), $1 \mathrm{mg} / \mathrm{mL}$ estradiol-17 $\beta, 10 \mathrm{mg} / \mathrm{mL}$ follicle-stimulating hormone, $0.6 \mu \mathrm{M}$ cysteine and $0.2 \mu \mathrm{M}$ sodium pyruvate, and then transferred to a 4 -well dish containing $600 \mu \mathrm{L}$ of IVM media in a humidified atmosphere of $5 \% \mathrm{CO}_{2}$ in air at $38.5^{\circ} \mathrm{C}$ for $22-24 \mathrm{~h}$.

\section{In vitro fertilization (IVF) followed by in vitro culture}

Matured COCs were fertilized as described by Deb and coworkers (Deb et al. 2011). Semen was thawed in water at $37^{\circ} \mathrm{C}$ for $1 \mathrm{~min}$, and sperm were washed and pelleted in D-PBS by centrifugation at $750 \mathrm{~g}$, room temperature for $5 \mathrm{~min}$. The pellet was resuspended in $500 \mu \mathrm{L}$ of heparin $(20 \mu \mathrm{g} / \mathrm{mL})$ prepared in IVF medium (Tyrode's lactate solution supplemented with $6 \mathrm{mg} / \mathrm{mL}$ bovine serum albumin (BSA), $22 \mathrm{mg} / \mathrm{mL}$ sodium pyruvate, $100 \mathrm{IU} / \mathrm{mL}$ penicillin and $0.1 \mathrm{mg} / \mathrm{mL}$ streptomycin) and incubated in a humidified atmosphere of $5 \% \mathrm{CO}_{2}$ in air at $38.5^{\circ} \mathrm{C}$ for $15 \mathrm{~min}$ (to facilitate capacitation). The sperm pellet was diluted in IVF medium (final density of $1-2 \times 10^{6} \mathrm{sperms} / \mathrm{mL}$ ).

Table 3 Characteristics of Day 8 blastocysts in the two groups.*

\begin{tabular}{lccc}
\hline Treatment & $\begin{array}{c}\text { No. of blastocysts } \\
\text { examined }\end{array}$ & $\begin{array}{c}\text { Total no. of cells } \\
\text { per blastocyst }\end{array}$ & $\begin{array}{c}\text { No. of apoptotic } \\
\text { cells per } \\
\text { blastocyst }\end{array}$ \\
\hline Control & 17 & $131.4 \pm 2.05^{\mathrm{a}}$ & $10.80 \pm 0.52^{\mathrm{b}}$ \\
$5 \mu \mathrm{M}$ coa-A & 17 & $143.1 \pm 1.51^{\mathrm{b}}$ & $6.400 \pm 0.47^{\mathrm{a}}$ \\
\hline
\end{tabular}

This study was completed in four replications.

*Total number of cells and number of apoptotic cells per blastocyst are shown (mean \pm S.E.); $a, b$ values with different superscripts in the same column are significantly different $(P<0.05)$. 
Matured oocytes were transferred to IVF medium $(600 \mu \mathrm{L})$ containing sperm for 18-20h. After IVF, cumulus cells were removed by pipetting, and denuded presumed zygotes were placed in $600 \mu \mathrm{L}$ of CR1-aa medium (Rosenkrans et al. 1993) supplemented with $44 \mu \mathrm{g} / \mathrm{mL}$ sodium pyruvate, $14.6 \mu \mathrm{g} / \mathrm{mL}$ glutamine, $10 \mu \mathrm{L} / \mathrm{mL}$ penicillin-streptomycin, $3 \mathrm{mg} / \mathrm{mL}$ BSA and $310 \mu \mathrm{g} / \mathrm{mL}$ glutathione for 3 days. After checking cleavage, 8-cell stage embryos were cultured until Day 8 of embryonic development (Day 0 = day of IVF) in medium of the same composition, except that FBS replaced BSA. Day 8 blastocysts
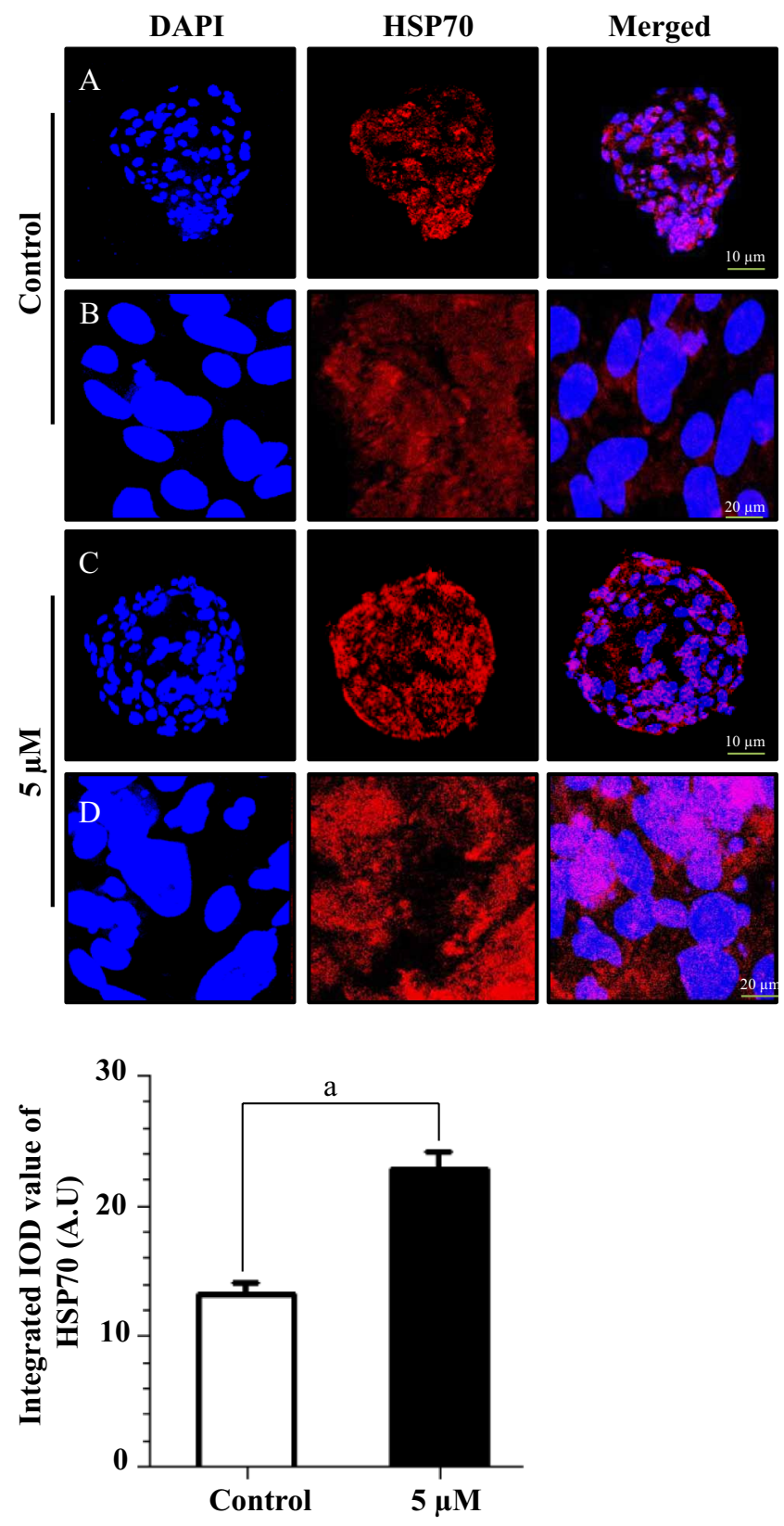

Figure 2 Confocal microscopy, showing HSP70 expression at a magnification of $10 \times$. (A, B) Control group, (C, D) coa-A treated group. The symbol a shows the significant difference $(P<0.05)$ between the control and coa-A treated group. The scale bar for $A$ and $C$ is $10 \mu \mathrm{m}$, whereas for $B$ and $D$ is $20 \mu \mathrm{m}$. were washed three times in TL-HEPES, transferred to fixative $(4 \%(\mathrm{v} / \mathrm{v})$ paraformaldehyde prepared in $1 \mathrm{M}$ PBS $)$ and stored at $4^{\circ} \mathrm{C}$ until cells were counted.

\section{Terminal deoxynucleotidyl transferase dUTP nick-end labeling (TUNEL) staining}

TUNEL was performed using an In Situ Cell Death Detection Kit according to the manufacturer's protocol (Roche Diagnostics Corp.). Fixed embryos were permeabilized $(0.5 \%(\mathrm{v} / \mathrm{v})$ Triton
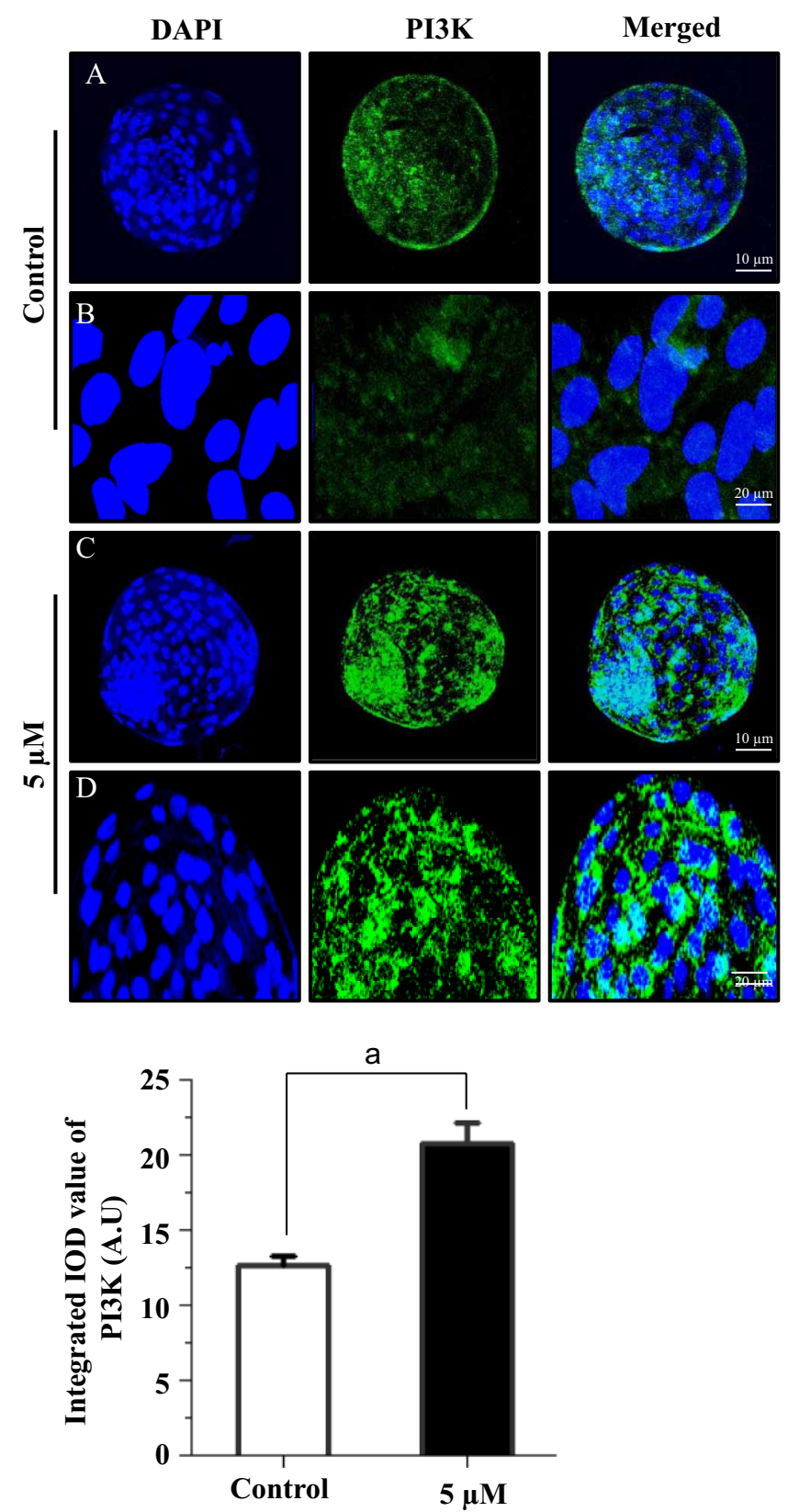

Figure 3 Confocal microscopy of bovine embryos in vitro showing $\mathrm{PI3K}$ expression in two groups at a magnification of 10x. (A, B) Control group, (C, D) coa-A treated group. The symbol a shows the significant difference $(P<0.05)$ between the control and coa-A treated group. The scale bar for $A$ and $C$ is $10 \mu \mathrm{m}$, whereas for $B$ and $D$ is $20 \mu \mathrm{m}$. 
$\mathrm{X}-100$ and $0.1 \%(\mathrm{w} / \mathrm{v})$ sodium citrate) at room temperature for $30 \mathrm{~min}$ and then washed twice with $0.3 \%(\mathrm{w} / \mathrm{v})$ polyvinyl alcohol prepared in 1 M PBS (PVA-PBS) (Deb et al. 2011). After permeabilization, embryos were washed twice with PVAPBS and incubated in the dark with fluorescently conjugated TUNEL at $37^{\circ} \mathrm{C}$ for $1 \mathrm{~h}$. TUNEL-stained embryos were then washed with PVA-PBS and incubated in PVA-PBS containing $10 \mu \mathrm{g} / \mathrm{mL}$ Hoechst 33342 for $10 \mathrm{~min}$. After washing, blastocysts were mounted on a glass slide, and their nuclear configuration was analyzed. An epifluorescence microscope (Olympus IX71) equipped with a mercury lamp was used to determine
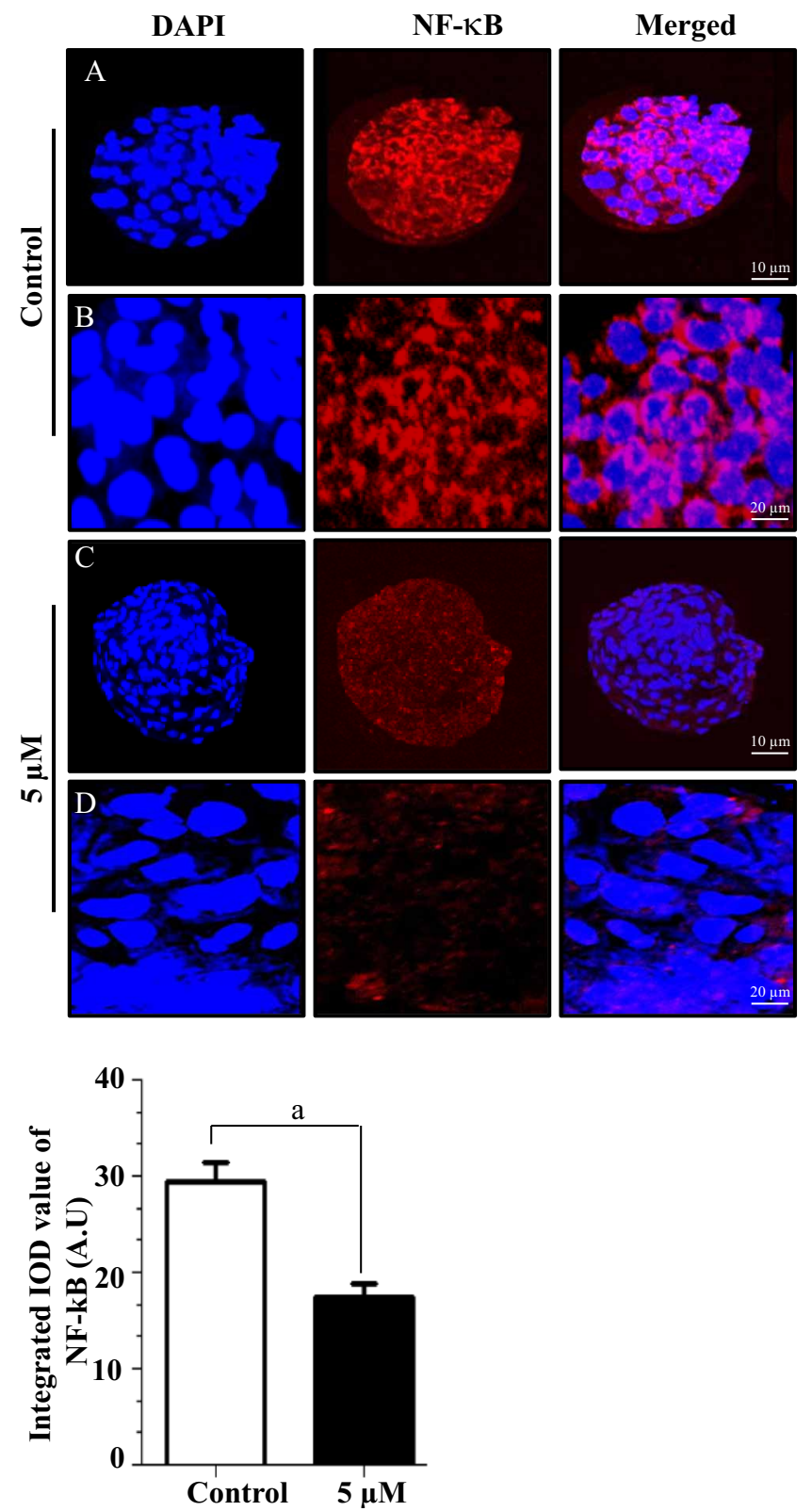

Figure 4 Confocal microscopy of NF-kB in two groups at a magnification of $10 \times$. (A, B) Control group, (C, D) coa-A treated group. The symbol a shows the significant difference $(P<0.05)$ between the control and coa-A treated group. $A$ and $C$ have a scale bar of $10 \mu \mathrm{m}$, whereas B and D have a scale bar of $20 \mu \mathrm{m}$. the number of cells per blastocyst by counting Hoechst-stained cells. Red cells (TUNEL positive) were apoptotic.

\section{Confocal microscopy (immunofluorescence analysis)}

Fixed embryos were washed twice with $1 \mathrm{M}$ PBS for $10 \mathrm{~min}$. Embryos were incubated in proteinase $\mathrm{K}$ solution at $37^{\circ} \mathrm{C}$
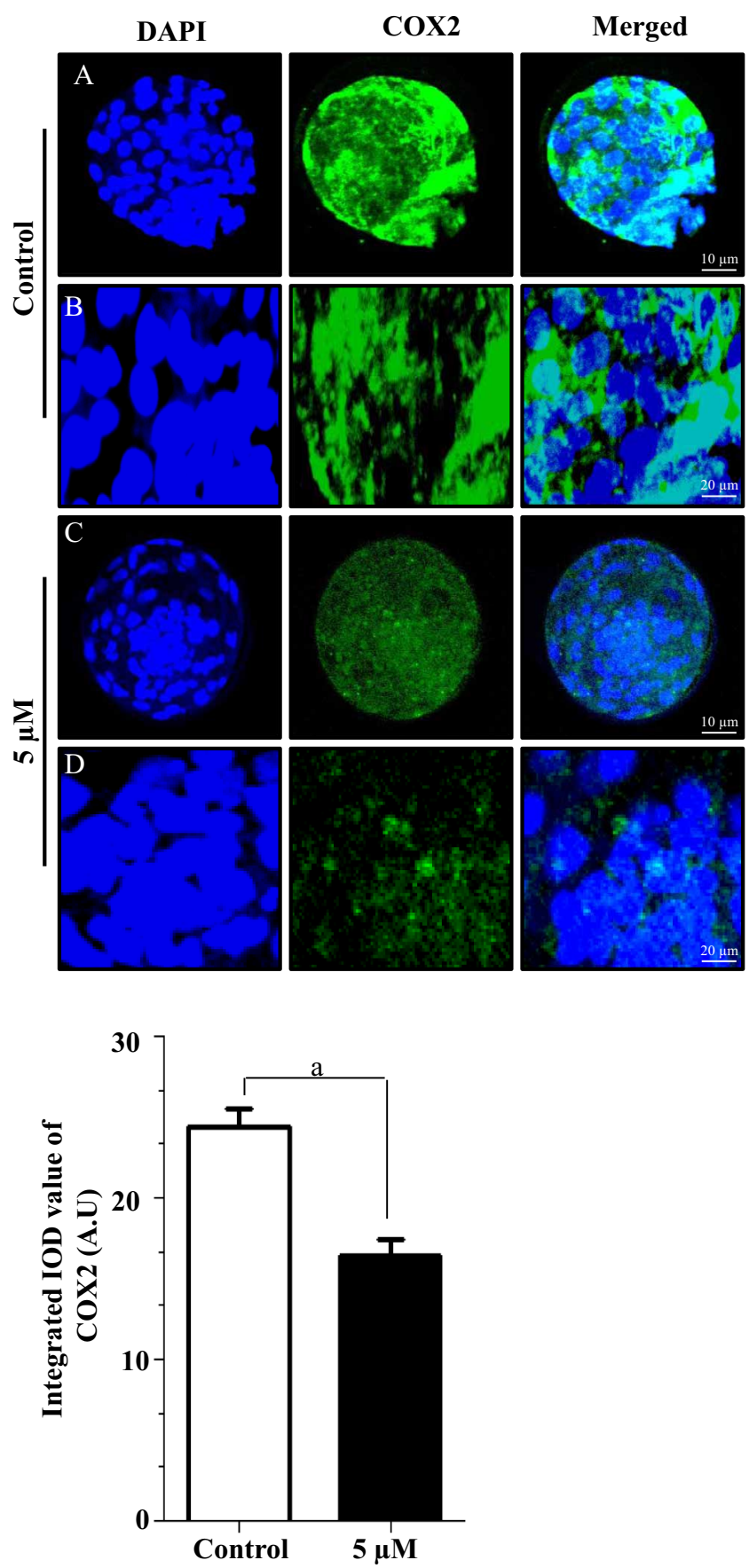

Figure 5 Confocal microscopy of COX2 in two groups at a magnification of 10×. (A, B) Control group; (C, D) coa-A treated group. The symbol a shows the significant difference $(P<0.05)$ between the control and coa-A treated group. The scale bar for $A$ and $C$ is $10 \mu \mathrm{m}$, whereas for $B$ and $D$ is $20 \mu \mathrm{m}$. 
for 5 min. Embryos were incubated in blocking solution (PBS containing 5\% non-immune goat serum and $0.3 \%$ Triton X-100) for $1 \mathrm{~h}$ after washing with PBS. Embryos were incubated overnight with primary antibodies including mouse-derived anti-phosphatidylinositol-3-kinase (PI3K), antiheat shock protein 70 (HSP70), anti-nuclear factor kappa B (NF-kB) (Santa Cruz Biotechnology) and anti-cyclooxygenase (COX2) (Millipore, Santa Cruz Biotechnology) antibodies, and then with secondary FITC- and TRITC-conjugated antibodies (diluted 1:50 in D-PBS; Santa Cruz Biotechnology) at room temperature for $90 \mathrm{~min}$. DAPI was used as a counterstain for 5 min. Embryos were mounted on glass slides with Prolong anti-fade reagent (Molecular Probes). Stained embryos were examined using a confocal laser-scanning microscope (Flouview FV 1000, Olympus). Then, the integral optical density (IOD) has been analyzed using Image software (https://imagej.nih.gov/ij/). Negative control was obtained by replacing the primary antibody with goat serum, whereas positive control was obtained by checking the expression of various proteins in cumulus cells (Supplementary Fig. 1, see section on supplementary data given at the end of this article).

\section{mRNA extraction and cDNA formation}

An Arcturus PicoPure RNA Isolation Kit (Arcturus, Foster, CA USA; Cat\# 12204-01) was used to extract RNA. In brief, $100 \mu \mathrm{L}$ of extraction buffer was added to the tube and incubated at $42^{\circ} \mathrm{C}$ for $30 \mathrm{~min}$. After incubation, the tube was centrifuged at $3000 \mathrm{~g}$ for $2 \mathrm{~min}$, and the supernatant was transferred to a new $1.5 \mathrm{~mL}$ RNA-free tube. Thereafter, $200 \mu \mathrm{L}$ of conditioning buffer was added to a column tube, incubated at room temperature for $5 \mathrm{~min}$ and then centrifuged at $16,000 \mathrm{~g}$ for $1 \mathrm{~min}$. Thereafter, $100 \mu \mathrm{L}$ of $70 \%$ ethanol was added and pipetted thoroughly. Then, the mixture was added to a column tube, centrifuged at $100 \mathrm{~g}$ for $2 \mathrm{~min}$, and then centrifuged at $16,000 \mathrm{~g}$ for $30 \mathrm{~s}$ to remove the flowthrough. Thereafter, $100 \mu \mathrm{L}$ of wash buffer 1 was added to the column and centrifuged at $8000 \mathrm{~g}$ for $1 \mathrm{~min}$. DNase I solution ( $5 \mu \mathrm{L}$ DNase added to $35 \mu \mathrm{L}$ of buffer RDD) was prepared and mixed gently. Then, $40 \mu \mathrm{L}$ of the DNase I mixture was added directly to the purification column membrane and incubated at room temperature for $15 \mathrm{~min}$. Thereafter, $40 \mu \mathrm{L}$ of wash buffer 1 was added to the column and centrifuged at $8000 \mathrm{~g}$ for $15 \mathrm{~s}$. Then, $100 \mu \mathrm{L}$ of wash buffer 2 was added to the column, centrifuged at $16,000 \mathrm{~g}$ for $2 \mathrm{~min}$, and then centrifuged at $16,000 \mathrm{~g}$ for $1 \mathrm{~min}$ to completely remove the wash buffer. Finally, the purification column was transferred to a new $1.5 \mathrm{~mL}$ RNase-free tube. Thereafter, $20 \mu \mathrm{L}$ of elution buffer was placed into the center of the column, incubated at room temperature for $1 \mathrm{~min}$, centrifuged at $1000 \mathrm{~g}$ for $1 \mathrm{~min}$ and then centrifuged at $16,000 \mathrm{~g}$ for $1 \mathrm{~min}$. RNA samples were used immediately or stored at $-80^{\circ} \mathrm{C}$ until use.

The RNA concentration and purity were checked using a NANO DROP 2000c machine (Thermo Fisher Scientific).
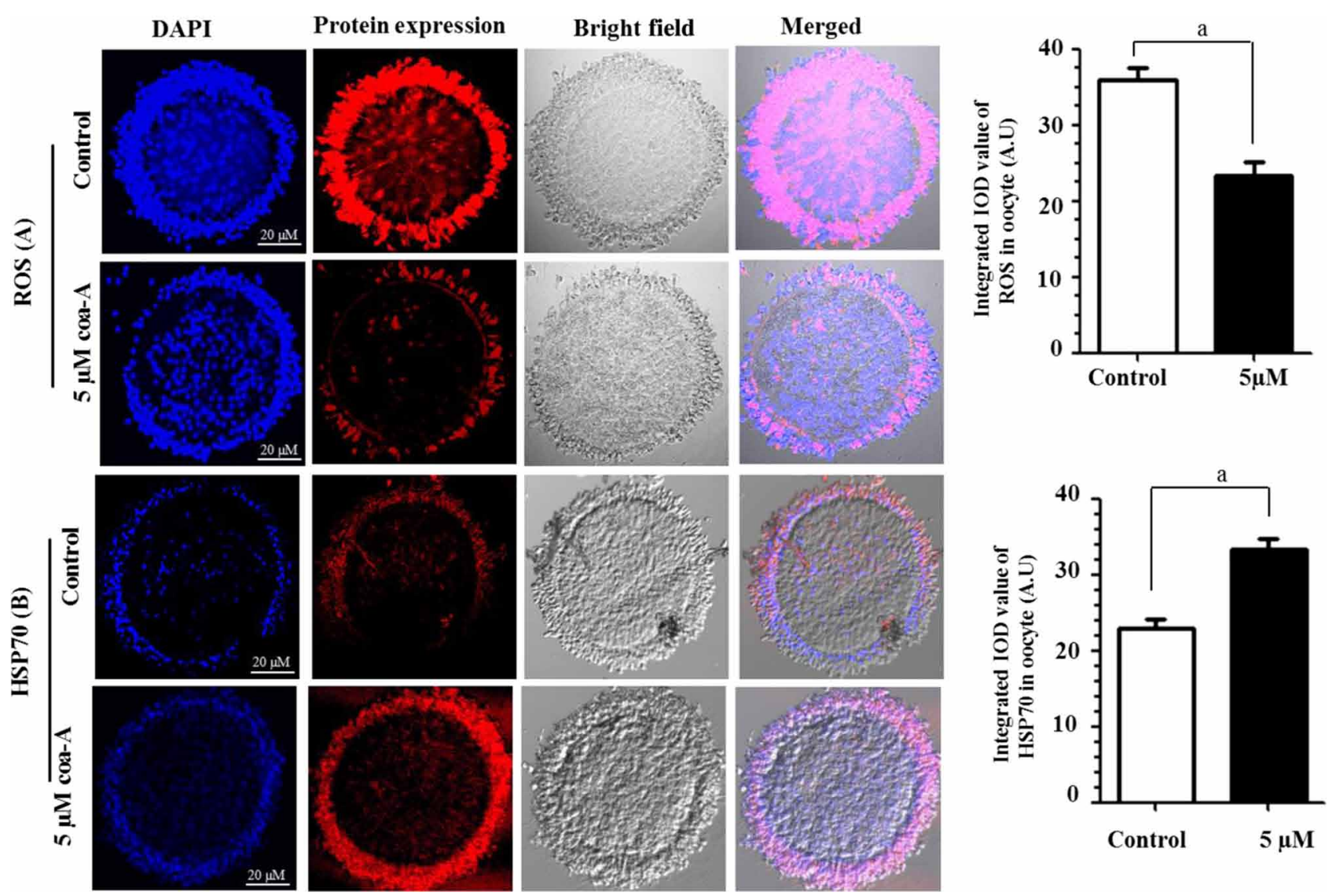

Figure 6 Confocal microscopy of HSP70 and ROS in oocytes at a magnification of 40×. (A) ROS (8-OxoG) expression, (B) HSP70 expression. The symbol a shows the significant difference $(P<0.05)$ between the control and coa-A treated groups. The scale bar is $700 \mu \mathrm{m}$. 
The mRNA samples were reverse-transcribed into first-strand cDNA using a kit from Bio-Rad Laboratories. The $15 \mu \mathrm{L}$ mRNA samples were transferred to a $200-\mu \mathrm{L}$ Eppendorf tube containing $4 \mu \mathrm{L}$ of $5 \times$ iScript Reaction Mixture and $1 \mu \mathrm{L}$ of iScript Reverse Transcriptase. The reactions was terminated by heating at $25^{\circ} \mathrm{C}$ for $5 \mathrm{~min}, 42^{\circ} \mathrm{C}$ for $30 \mathrm{~min}$ and $85^{\circ} \mathrm{C}$ for $5 \mathrm{~min}$, and finally samples were held at $4^{\circ} \mathrm{C}$.

\section{Real-time PCR analysis of target genes}

Selected genes of heat shock protein 70 (HSP70), phosphatidylinositol-3-kinase $(P I 3 K)$, nuclear factor kappa B $(N F-\kappa B)$, cyclooxygenase-2 (COX2), inducible nitric oxide synthase (iNOS), bcl-2-associated $X$ protein $(B A X), B$-cell lymphoma 2 (BCL-2), cyclin-dependent kinase inhibitor (P21), tumor protein (P53) and caspase 3 were analyzed by realtime PCR. Quantitative RT-PCR was performed in duplicate using a CFX98 instrument (Bio-Rad Laboratories) with a $10-\mu \mathrm{L}$ reaction mixture containing $0.2 \mathrm{mM}$ of each bovine-specific primer (Table 1), 1× iQ SYBR Green Supermix (iQ SYBR Green Supermix kit, Bio-Rad Laboratories) and $3 \mu \mathrm{L}$ of diluted cDNA. All cDNA samples were subjected to real-time PCR using glyceraldehyde-3-phosphate dehydrogenase (GAPDH) primers to detect any variation in expression of this internal control gene. After confirming that relative GAPDH expression did not significantly differ among the samples, all transcripts were quantified using independent real-time PCR analyses. The cycling conditions were as follows: $95^{\circ} \mathrm{C}$ for $3 \mathrm{~min}$, followed by 44 cycles of $95^{\circ} \mathrm{C}$ for $15 \mathrm{~s}, 57^{\circ} \mathrm{C}$ for $20 \mathrm{~s}$ and $72^{\circ} \mathrm{C}$ for $30 \mathrm{~s}$, and a final extension at $72^{\circ} \mathrm{C}$ for $5 \mathrm{~min}$. Amplification was followed by melting curve analysis using progressive denaturation, during which the temperature was increased from $65^{\circ} \mathrm{C}$ to $95^{\circ} \mathrm{C}$ at a rate of $0.2^{\circ} \mathrm{C}$ per second. Fluorescence was continuously measured during this incremental heating. Quantitative analysis was performed using the $\Delta \Delta C(\mathrm{t})$ method. The results are reported as the relative expression or $n$-fold difference compared with the calibrator after normalization of the transcript to the average value of the endogenous control GAPDH. The coefficients of variation of the intra- and interassay variance were calculated according to the formula, S.D./ mean $\times 100$, for all genes profiled by real-time PCR.

\section{Statistical analysis}

Results are presented as percentages. Prism 5 was used to analyze the data and total cell numbers per blastocyst. The data are presented as the mean \pm standard error of mean (S.E.M.). A simple $t$-test and one-way ANOVA were used to detect significant differences between groups. $P<0.05$ was considered significant.

\section{Results}

\section{Cleavage and developmental rates of embryos in heat stress conditions}

The cleavage rate was determined on the third day of culture. The cleavage rate was not significantly higher in the $5 \mu \mathrm{M}$ coa-A-treated group than that in the control group after exposure to heat shock for $2 \mathrm{~h}(82.3 \%$ and $80.2 \%), 5 \mathrm{~h}$ (79.3\% and $78.5 \%), 10 \mathrm{~h}(77.3 \%$ and $78.1 \%), 20 \mathrm{~h}(76.2 \%$ and $75.7 \%$ ) and after $24 \mathrm{~h}(53.7 \%$ and $52.1 \%)$, respectively, but this increase in cleavage between different groups was not statistically significant. However, the percentage of Day 8 blastocysts was significantly higher $(P<0.05)$ in the $5 \mu \mathrm{M}$ coa-A-treated group than that in the control group after exposure to heat shock for $2 \mathrm{~h}(36.1 \%$ and $26.6 \%)$, $5 \mathrm{~h}(32.6 \%$ and $24.7 \%), 10 \mathrm{~h} \mathrm{(29.2 \%} \mathrm{and} 21.8 \%)$ and $20 \mathrm{~h}$ (24.6\% and $18.6 \%$ ) respectively, but for $24-\mathrm{h}$ exposure to heat shock there was no significant difference between the coa-A-treated group and the control group (15.2\% and 14.2\%) (Table 2).

\section{Determination of the numbers of total cells and apoptotic cells per blastocyst}

The total number of cells per Day 8 blastocyst was significantly higher $(P<0.05)$ in the $5 \mu \mathrm{M}$ coa-Atreated group $(143.1 \pm 1.5)$ than that in the control group (131.4 \pm 2.0 ) (Fig. 1 and Table 2). The number of apoptotic cells per Day 8 blastocyst was significantly lower $(P<0.05)$ in the $5 \mu \mathrm{M}$ coa-A-treated group $(6.4 \pm 0.5)$ than that in the control group $(10.8 \pm 0.5)$ (Fig. 1 and Table 3).

\section{Induction of HSP70 and PI3K through coa-A in heat stress conditions}

The role of HSP70 in the development of blastocyst was analyzed through immunofluorescence analysis. The integral optical density (IOD) of HSP70 was significantly higher $(P<0.05)$ in the $5 \mu \mathrm{M}$ coa-A-treated group than that in the control group (Fig. 2). In the same way, the expression of $\mathrm{PI} 3 \mathrm{~K}$ protein was analyzed and the IOD was higher $(P<0.05)$ in the $5 \mu \mathrm{M}$ coa-A-treated group than that in the control group (Fig. 3).

\section{Coa- $A$ attenuates $N F-\kappa B$ and COX2 expression}

Immunofluorescence analysis revealed that the IOD of NF- $\kappa$ B protein was lower $(P<0.05)$ in the $5 \mu \mathrm{M}$ coaA-treated group than that in the control group (Fig. 4). Similarly, it was also confirmed through confocal microscopy that the COX2 expression was significantly attenuated $(P<0.05)$ in the $5 \mu \mathrm{M}$ coa-A-treated group than that in the control group (Fig. 5).

\section{Immunofluorescence analysis of HSP70 and ROS (8-OxoG) in oocytes}

The immunofluorescence analysis shows that the IOD of HSP70 in oocytes is significantly higher in the $5 \mu \mathrm{M}$ coaA-treated group than that in the control group (Fig. 6A). Similarly, the IOD of ROS (8-OxoG) in oocytes is lower in the $5 \mu \mathrm{M}$ coa-A-treated group than that in the control group (Fig. 6B). 

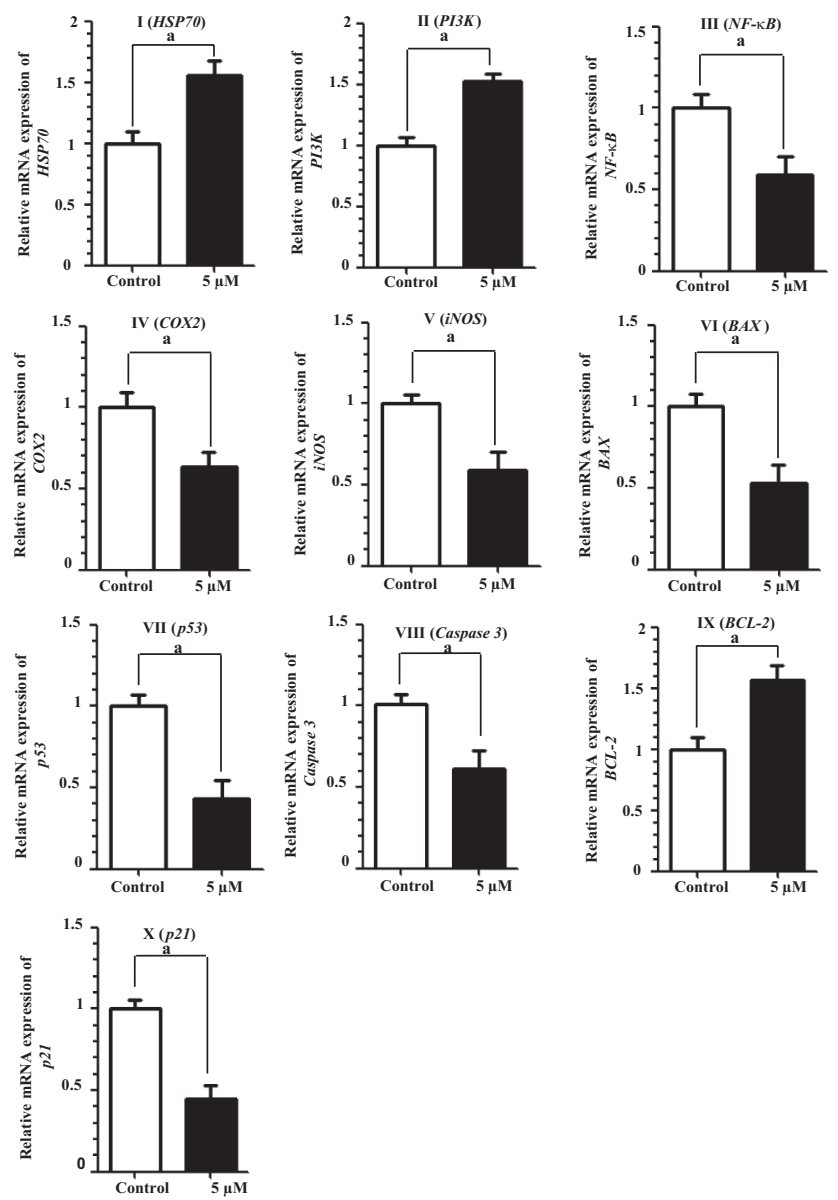

Figure 7 Relative mRNA expression profile of various genes $(\mathrm{I}-\mathrm{X})$ in control and coa-A treated blastocysts by real-time PCR. The symbol a shows the significant difference $(P<0.05)$ between the control and coa-A treated group.

\section{mRNA expression of related genes}

RT-PCR was performed to determine the expression levels of ten genes including heat stress-related gene HSP70, oxidative stress-related genes; NF- $\kappa B, C O X 2$, iNOS, PI3K, pro-apoptotic genes; P53, P21, caspase 3, $B A X$ and anti-apoptotic gene $B C L-2$ and normalized against the housekeeping gene GAPDH. Expression levels of HSP7O, PI3K and BCL-2 were significantly higher $(P<0.05)$ in the $5 \mu \mathrm{M}$ coa-A-treated group than that in the control group. However, the expression levels of NF- $\kappa B, C O X 2$, iNOS, P53, P21, caspase 3 and BAX were significantly lower in the $5 \mu \mathrm{M}$ coa-A-treated group than that in the control group (Fig. 7).

\section{Discussion}

During summer, when the temperature increases from June to September, the fertility rate of cattle decreases (Hansen 1997). Heat stress reduces the developmental competence of oocytes, which leads to poor fertilization (Roth et al. 2001). Heat stress perturbs oocyte maturation,

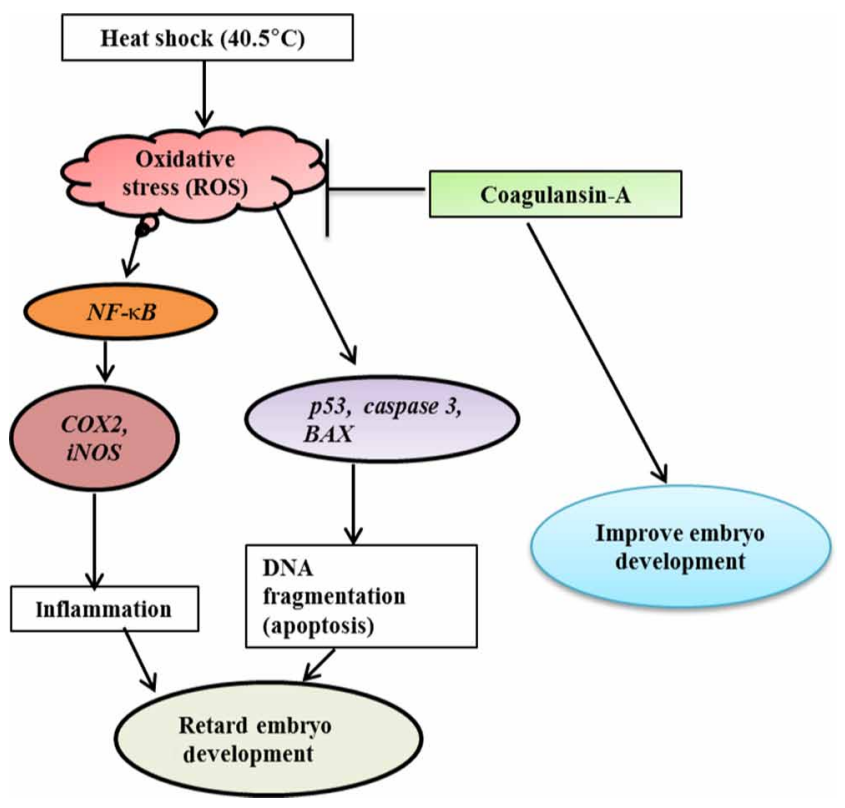

Figure 8 Proposed pathway of coagulansin-A.

which leads to poor blastocyst development (Roth \& Hansan 2004a). Here, we are reporting for the first time that $5 \mu \mathrm{M}$ coa-A treatment in IVM stage improves blastocyst development in heat stress conditions of $40.5^{\circ} \mathrm{C}$ for $20 \mathrm{~h}$. The blastocyst formation rate at $40.5^{\circ} \mathrm{C}$ after 20 -h heat shock in the control group was $18.6 \%$ in the current study, which is in close agreement with a previous study (Roth \& Hansan 2004b); however, addition of $5 \mu \mathrm{M}$ coa-A to the IVM media significantly improved this rate to $24.6 \%$.

The numbers of apoptotic and total cells are key factors for embryo quality; the higher the number of cells in an implanted embryo, the higher the chance of live offspring being delivered (van Soom et al. 2007). In the present study, coa-A treatment in IVM media at a heat stress of $40.5^{\circ} \mathrm{C}$ for $20 \mathrm{~h}$ improved blastocyst quality by increasing the total number of cells and decreasing the apoptotic index compared with the control group, which is in agreement with our previous findings at a normal culture temperature (Khan et al. 2016).

Heat shock proteins counterbalance the detrimental effects of any type of stress (Lindquist \& Craig 1988). Among the heat shock proteins, HSP70 is very important, because its production is higher in vitro than in vivo due to the high level of stress in vitro (Sharma et al. 2012). HSP70 also protects cells during heat stress condition (Hendrey \& Kola 1991) and works as a molecular chaperone in normal physiology (Ellis \& van der Vies 1991). Heat shock induces apoptosis, which is blocked at various points by HSP70 (Mosser et al. 1997). We previously reported that the coa-A induces HSP70 in bovine, which improves blastocyst quality and the blastocyst formation efficiency at normal culture condition (Khan et al. 2016). In the present study, at heat stress condition, we also confirmed that coa-A improves 
the blastocyst formation efficiency via induction of HSP70. This improvement of blastocyst through HSP70 induction is consistent with Matwee and coworkers (Matwee et al. 2001).

The PI3K lipid kinase pathway has a very important role in cell survival and is activated during mild oxidative stress (Datta et al. 1999, Sonoda et al. 1999). PI3K is also involved in growth factor-dependent survival of diverse types of cultured cells (Scheid et al. 1995, Ulrich et al. 1998, Fruman et al. 1999). In the current study, coa-A treatment increased the expression of PI3K compared with that in the control group, and this in turn improved the survival of blastocysts through the suppression of apoptosis, which is in agreement with a previous study (Yao \& Cooper 1995).

$N F-\kappa B$ gene was first identified as a transcription factor in 1986 (Sen \& Baltimore 1986). NF-kB has a critical role in all cellular processes (Hayden \& Ghosh 2008). It is a multidirectional nuclear transcription factor that has roles in inflammation, oxidative stress and apoptosis (Brasier 2006, Gilmore 2006). NF-кB is activated in the nucleus, but can be inhibited by ІкB inhibition in the cytoplasm. In the present study, coa-A improved blastocyst development in heat stress conditions by attenuating NF-kB expression, which is in agreement with previous studies (Heyninck et al. 2014, Khan et al. 2016).

Inflammation in mammals is mediated and enhanced by various pro-inflammatory mediators, among which COXs are very important (Matheus et al. 2007). The COX family comprises COX1, COX2 and COX3. COX2 is the most important COX, induced in the cytoplasm and is involved in inflammatory and neoplastic processes (Thorat et al. 2013). In the current study, COX2 expression was attenuated in the $5 \mu \mathrm{M}$ coa-A-treated group compared with that in the control group. This decrease in COX2 expression is in agreement with a previous study (Yan et al. 2015).

All organisms respond to the environmental stress through heat shock proteins (Becker \& Craig 1994). HSP70 is one of the most important heat shock protein, which is found on the acrosome of bovine spermatozoa and plays a role in oocyte and sperm interaction (Kamaruddin 1988). The mRNA microinjection of HSP7O gene to oocyte increased their resistance to heat stress (Hendrey \& Kola 1991). In the present study, the coa-A protects the oocytes against the heat stress through the induction of HSP70 proteins, which is in agreement with a previous report (Hendrey \& Kola 1991).

Reactive oxygen species (ROS) are very harmful in high concentration and damages the spermatozoa leading to male infertility (Iwasaki \& Gagnon 1992). ROS and antioxidant should be balanced for normal embryo development (Patel et al. 2007). The 8-OxoG is a common marker for ROS detection (Floyd 1990). In the present study, we found that the $5 \mu \mathrm{M}$ of coa-A supplementation in IVM significantly reduces the ROS concentration in oocytes compared to control group, which is parallel to our previous finding (Khan et al. 2016).

In the present study, the expression levels of HSP70, PI3K, NF-KB, COX2, iNOS and BAX genes were investigated in the control and $5 \mu \mathrm{M}$ coa-A-treated groups. Supplementation of coa- $A$ in heat stress conditions upregulated expression of HSP7O, which is in agreement with a study by Wang and coworkers (Wang et al. 2012). The coa-A increased the expression of PIJK, and this improved the blastocyst quality by suppressing apoptosis, which is in agreement with a previous study (Yao \& Cooper 1995). NF-кB, COX2 and iNOS are very important genes, which favor inflammation and play a main role in cancer and neoplastic anemia (Karin et al. 2002, Thorat et al. 2013). Our results are in agreement with our previous findings (Khan et al. 2016, Zhao et al. 2016) because coa-A suppresses the expression of $N F-\kappa B$ and COX2 as well as $i N O S$. The tumor suppressor $P 53$ and cyclin-dependent kinase inhibitor $P 21$ have main role in early apoptosis and cell cycle arrest (Ko \& Prives 1996). Similarly, the $B A X$ and caspase 3 are also very important and working as pro-apoptotic genes (Pang et al. 2016). In contrast, the $B C L-2$ is an anti-apoptotic gene that suppresses the apoptosis (Guénal et al. 1997). In the present study, we found that the $5 \mu \mathrm{M}$ coa-A significantly suppresses the expression of P53,P21, BAX and caspase 3 while induces the expression of $B C L-2$ and hence reduces the apoptosis, which is in agreement with Guénal and coworkers (Guénal et al. 1997).

In conclusion, as shown in Fig. 8, our results demonstrated that the heat shock (at $40.5^{\circ} \mathrm{C}$ ) increases the ROS concentration, which results in the inflammation due to the induction of $N F-\kappa B$ and their subsequent $C O X 2$ and $i N O S$, similarly the $P 53$ and $B A X$ are also induces by the ROS which compromise the blastocyst quality and efficiency. The $5 \mu \mathrm{M}$ coa-A when supplemented in the IVM media after a heat shock of $20 \mathrm{~h}$ at $40.5^{\circ} \mathrm{C}$ induced the HSP7O and PI3K while offset the ROS and block their subsequent pathway leading to improve the blastocyst development. Furthermore, although the current findings indicate the beneficial effect of coa-A against heat shock at $40.5^{\circ} \mathrm{C}$, but we also observed that this effect of coa-A was completely diminished by the condition like high temperature $\left(42^{\circ} \mathrm{C}\right)$. This shows that this beneficial effect of coa-A is limited specifically to heat shock $40.5^{\circ} \mathrm{C}$.

\section{Supplementary data}

This is linked to the online version of the paper at http://dx.doi. org/10.1530/REP-16-0530.

\section{Declaration of interest}

The authors declare that there is no conflict of interest that could be perceived as prejudicing the impartiality of the research reported. 


\section{Funding}

This work was partly supported by a grant from the NextGeneration BioGreen 21 Program (No. PJ01107703). Imran Khan, Kyeong-lim Lee, Xu Lianguang, Mesalam Ayman, Muhammad Mustafizur Rahman Chowdhury and MyeongDon Joo were supported by a scholarship from the BK21 Plus program. Mesalam Ayman was supported by the Korean Government Scholarship Program (KGSP), Ministry of Education, Republic of Korea.

\section{Acknowledgements}

The authors are grateful to Dr Shahid Ali Shah for his kind help with confocal microscopy and antibody treatments.

\section{References}

Becker J \& Craig EA 1994 Heat shock proteins as a molecular chaperon. European Journal of Biochemistry 219 11-23. (doi:10.1111/j.1432-1033.1994.tb19910.x)

Brasier AR 2006 The NF-kB regulatory network. Cardiovascular Toxicology 6 111-130. (doi:10.1385/CT:6:2:111)

Cavestany D, El-Wishy A \& Foote R 1985 Effect of season and high environmental temperature on fertility of Holstein cattle. Journal of Dairy Science 68 1471-1478. (doi:10.3168/jds.S0022-0302(85)80985-1)

Combelles CM, Gupta S \& Agarwal A 2009 Could oxidative stress influence the in-vitro maturation of oocytes? Reproductive Biomedicine Online $\mathbf{1 8}$ 864-880. (doi:10.1016/S1472-6483(10)60038-7)

Datta SR, Brunet A \& Greenberg ME 1999 Cellular survival: a play in three Akts. Genes and Development 13 2905-2927. (doi:10.1101/ gad.13.22.2905)

De Rensis F, Marconi P, Capelli T, Gatti F, Facciolongo F, Franzini S \& Scaramuzzi R 2002 Fertility in postpartum dairy cows in winter or summer following estrus synchronization and fixed time Al after the induction of an LH surge with GnRH or hCG. Theriogenology 58 1675-1687. (doi:10.1016/S0093-691X(02)01075-0)

Deb G, Dey S, Bang J, Cho S, Park H, Lee J \& Kong I 2011 9-Retinoic acid improves developmental competence and embryo quality during in vitro maturation of bovine oocytes through the inhibition of oocyte tumor necrosis factor- $\alpha$ gene expression. Journal of Animal Science $\mathbf{8 9}$ 2759-2767. (doi:10.2527/jas.2011-3848)

Ellis RJ \& van der Vies SM 1991 Molecular chaperones. Annual Review of Biochemistry 60 321-347. (doi:10.1146/annurev.bi.60.070191.001541)

Floyd RA 1990 The role of 8-hydroxyguanine in carcinogenesis. Carcinogenesis 11 1447-1450. (doi:10.1093/carcin/11.9.1447)

Fruman DA, Snapper SB, Claudine MY, Davidson L, Yu JY, Alt FW \& Cantley LC 1999 Impaired B cell development and proliferation in absence of phosphoinositide 3-kinase p85a. Science 283 393-397. (doi:10.1126/science.283.5400.393)

Gilmore TD 2006 Introduction to NF-kB: players, pathways, perspectives. Oncogene 25 6680-6684. (doi:10.1038/sj.onc.1209954)

Guénal I, Sidoti-de Fraisse C, Gaumer S \& Mignotte B 1997 Bcl-2 and Hsp27 act at different levels to suppress programmed cell death. Oncogene 15 347-360. (doi:10.1038/sj.onc.1201182)

Guerin P, El Mouatassim S \& Menezo Y 2001 Oxidative stress and protection against reactive oxygen species in the pre-implantation embryo and its surroundings. Human Reproduction Update 7 175-189. (doi:10.1093/humupd/7.2.175)

Hansen PJ 1997 Strategies for enhancing reproduction of lactating dairy cows exposed to heat stress. In Proceedings of the 16th Annual Convention American Embryo Transfer Association, Madison, pp 62-72.

Hansen PJ 2009 Effects of heat stress on mammalian reproduction. Philosophical Transactions of the Royal Society of London B: Biological Sciences 364 3341-3350. (doi:10.1098/rstb.2009.0131)

Hayden MS \& Ghosh S 2008 Shared principles in NF-kB signaling. Cell 132 344-362. (doi:10.1016/j.cell.2008.01.020)
Hendrey J \& Kola I 1991 Thermolability of mouse oocytes is due to the lack of expression and/or inducibility of Hsp70. Molecular Reproduction and Development 28 1-8. (doi:10.1002/mrd.1080280102)

Heyninck K, Lahtela-Kakkonen M, Van der Veken P, Haegeman G \& Berghe WV 2014 Withaferin A inhibits NF-kappaB activation by targeting cysteine 179 in IKK $\beta$. Biochemical Pharmacology 91 501-509. (doi:10.1016/j.bcp.2014.08.004)

Ihsan-ul-Haq, Youn UJ, Chai X, Park EJ, Kondratyuk TP, Simmons CJ \& Chang LC 2013 Biologically active withanolides from Withania coagulans. Journal of Natural Products 76 22-28. (doi:10.1021/ np300534x)

Iwasaki A \& Gagnon C 1992 Formation of reactive oxygen species in spermatozoa of infertile men. Fertility and Sterility 57 409-418. (doi:10.1016/S0015-0282(16)54855-9)

Jeong WJ, Cho SJ, Lee HS, Deb GK, Lee YS, Kwon TH \& Kong IK 2009 Effect of cytoplasmic lipid content on in vitro developmental efficiency of bovine IVP embryos. Theriogenology 72 584-589. (doi:10.1016/j. theriogenology.2009.04.015)

Kamaruddin MB 1988 Heat shock protein 70 in Bovine spermatogenesis and fertilization. PhD Thesis, University of Guelph, Ontario, Canada.

Karin M, Cao Y, Greten FR \& Li ZW 2002 NF-kappaB in cancer: from innocent bystander to major culprit. Nature Reviews Cancer 2 301-310. (doi:10.1038/nrc780)

Khan I, Lee KL, Fakruzzaman M, Song SH, Mirza B, Yan CG \& Kong IK 2016 Coagulansin-A has beneficial effects on the development of bovine embryos in vitro via HSP70 induction. Bioscience Reports $\mathbf{3 6}$ e00310. (doi:10.1042/BSR20150222)

Ko LJ \& Privas C 1996 p53: puzzle and paradigm. Genes and Development 10 1054-1072. (doi:10.1101/gad.10.9.1054)

Lindquist S \& Craig E 1988 The heat-shock proteins. Annual Review of Genetics 22 631-677. (doi:10.1146/annurev.ge.22.120188.003215)

Lonergan P, Fair T, Corcoran D \& Evans A 2006 Effect of culture environment on gene expression and developmental characteristics in IVF-derived embryos. Theriogenology 65 137-152. (doi:10.1016/j. theriogenology.2005.09.028)

Matheus AS, Coelho A, Maria M, Sampietre S, Patzina R, Jukemura J, Cunha JEM \& Machado MC 2007 Effect of inhibition of prostaglandin $E_{2}$ production on pancreatic infection in experimental acute pancreatitis. HPB 9 392-397. (doi:10.1080/13651820701646214)

Matwee C, Kamaruddin M, Betts DH, Basrur P \& King WA 2001 The effects of antibodies to heat shock protein 70 in fertilization and embryo development. Molecular Human Reproduction 7 829-837.

Mosser DD, Caron AW, Bourget L, Denis-Larose C \& Massie B 1997 Role of the human heat shock protein hsp70 in protection against stress-induced apoptosis. Molecular and Cellular Biology 17 5317-5327. (doi:10.1128/ MCB.17.9.5317)

Nabenishi H, Ohta H, Nishimoto T, Morita T, Ashizawa K \& Tsuzuki Y 2012 The effects of cysteine addition during in vitro maturation on the developmental competence, ROS, GSH and apoptosis level of bovine oocytes exposed to heat stress. Zygote 20 249-259. (doi:10.1017/ S0967199411000220)

Pang YW, Sun YQ, Sun WJ, Du WH, Hao HS, Zhao SJ \& Zhu HB 2016 Melatonin inhibits paraquat-induced cell death in bovine preimplantation embryos. Journal of Pineal Research 60 155-166. (doi:10.1111/jpi.12297)

Patel OV, Bettegowda A, Ireland J, Coussens PM, Lonergan P \& Smith GW 2007 Functional genomics studies of oocyte competence: evidence that reduced transcript abundance for follistatin is associated with poor developmental competence of bovine oocytes. Reproduction 133 95-106. (doi:10.1530/rep.1.01123)

Rosenkrans CF Jr, Zeng GQ, MCNamara GT, Schoff PK \& First NL 1993 Development of bovine embryos in vitro as affected by energy substrates. Biology of Reproduction 49 459-462. (doi:10.1095/ biolreprod49.3.459)

Roth Z 2008 Heat stress, the follicle, and its enclosed oocyte: mechanisms and potential strategies to improve fertility in dairy cows. Reproduction in Domestic Animals 43 238-244. (doi:10.1111/j.14390531.2008.01168.x)

Roth Z \& Hansen P 2004a Involvement of apoptosis in disruption of developmental competence of bovine oocytes by heat shock during maturation. Biology of Reproduction 71 1898-1906. (doi:10.1095/ biolreprod.104.031690) 
Roth Z \& Hansen P 2004 b Sphingosine 1-phosphate protects bovine oocytes from heat shock during maturation. Biology of Reproduction 71 2072-2078. (doi:10.1095/biolreprod.104.031989)

Roth Z, Arav A, Bor A, Zeron Y, Braw-Tal R \& Wolfenson D 2001 Improvement of quality of oocytes collected in the autumn by enhanced removal of impaired follicles from previously heat-stressed cows. Reproduction 122 737-744. (doi:10.1530/rep.0.1220737)

Scheid MP, Lauener R \& Duronio V 1995 Role of phosphatidylinositol 3-OH-kinase activity in the inhibition of apoptosis in haemopoietic cells: phosphatidylinositol 3-OH-kinase inhibitors reveal a difference in signalling between interleukin-3 and granulocyte-macrophage colony stimulating factor. Biochemical Journal 312 159-162. (doi:10.1042/bj3120159)

Sen R \& Baltimore D 1986 Inducibility of $\kappa$ immunoglobulin enhancerbinding protein NF- $\mathrm{KB}$ by a posttranslational mechanism. Cell 47 921-928. (doi:10.1016/0092-8674(86)90807-X)

Sharma G, Nath A, Prasad S, Singhal S, Singh N, Gade N, Dubey P \& Saikumar G 2012 Expression and characterization of constitutive heat shock protein 70.1 (HSPA-1A) gene in in vitro produced and in vivoderived buffalo (Bubalus bubalis) embryos. Reproduction in Domestic Animals 47 975-983. (doi:10.1111/j.1439-0531.2012.02002.x)

Sonoda Y, Watanabe S, Matsumoto Y, Aizu-Yokota E \& Kasahara T 1999 FAK is the upstream signal protein of the phosphatidylinositol 3-kinaseAkt survival pathway in hydrogen peroxide-induced apoptosis of a human glioblastoma cell line. Journal of Biological Chemistry 274 10566-10570. (doi:10.1074/jbc.274.15.10566)

Stott G 1961 Female and breed associated with seasonal fertility variation in dairy cattle. Journal of Dairy Science 44 1698-1704. (doi:10.3168/ jds.S0022-0302(61)89942-6)

Thorat D, Sahu A, Behera R, Lohite K, Deshmukh S, Mane A, Karnik S, Doke S \& Kundu GC 2013 Association of osteopontin and cyclooxygenase-2 expression with breast cancer subtypes and their use as potential biomarkers. Oncology Letters 6 1559-1564. (doi:10.3892/ ol.2013.1600)

Ulrich E, Duwel A, Kauffmann-Zeh A, Gilbert C, Lyon D, Rudkin B, Evan G \& Martin-Zanca D 1998 Specific TrkA survival signals interfere with different apoptotic pathways. Oncogene 16 825-832. (doi:10.1038/sj.onc.1201842)
Van Soom A, Vandaele L, Goossens K, de Kruif A \& Peelman L 2007 Gamete origin in relation to early embryo development. Theriogenology 68 S131-S137. (doi:10.1016/j.theriogenology. 2007.03.019)

Wang H-C, Tsai Y-L, Wu Y-C, Chang F-R, Liu M-H, Chen W-Y \& Wu C-C 2012 Withanolides-induced breast cancer cell death is correlated with their ability to inhibit heat protein 90. PLOS ONE 7 e37764. (doi:10.1371/ journal.pone.0037764)

Yadav A, Singh K, Singh M, Saini N, Palta P, Manik R, Singla S, Upadhyay R \& Chauhan M 2013 Effect of physiologically relevant heat shock on development, apoptosis and expression of some genes in buffalo (Bubalus bubalis) embryos produced in vitro. Reproduction in Domestic Animals 48 858-865. (doi:10.1111/ rda.12175)

Yan BC, Jeon YH, Park JH, Kim IH, Cho JH, Ahn JH, Chen BH, Tae HJ, Lee JC, Ahn JY et al. 2015 Increased cyclooxygenase-2 and nuclear factor-kappaB/p65 expression in mouse hippocampi after systemic administration of tetanus toxin. Molecular Medicine Reports 12 7837-7844. (doi:10.3892/mmr.2015.4490)

Yao R \& Cooper GM 1995 Requirement for phosphatidylinositol-3 kinase in the prevention of apoptosis by nerve growth factor. Science $\mathbf{2 6 7}$ 2003-2006. (doi:10.1126/science.7701324)

Zhao XM, Hao HS, Du WH, Zhao SJ, Wang HY, Wang N, Wang D, Liu Y, Qin T \& Zhu HB 2016 Melatonin inhibits apoptosis and improves the developmental potential of vitrified bovine oocytes. Journal of Pineal Research 60 132-141. (doi:10.1111/jpi.12290)

Ziauddin M, Phansalkar N, Patki P, Diwanay S \& Patwardhan B 1996 Studies on the immunomodulatory effects of Ashwagandha. Journal of Ethnopharmacology $\mathbf{5 0}$ 69-76. (doi:10.1016/03788741(95)01318-0)

Received 27 September 2016

First decision 21 November 2016

Revised manuscript received 11 December 2016

Accepted 9 January 2017 